\title{
El turismo y sus perspectivas para la región Junín, Perú
}

\section{Tourism and its prospects for the Junin region, Peru}

Ángela C. Ríos Cardozo

Universidad Continental

\section{INTRODUCCIÓN}

El turismo comprende las actividades que realizan las personas durante sus viajes y estancias en lugares distintos a su entorno habitual por un periódo consecutivo inferior a un año con fines de ocio, por negocios y otros motivos no relacionados con el ejercicio de una actividad remunerada en el lugar visitado. No es una industria en el sentido tradicional, por lo que no figura como tal en las clasificaciones utilizadas en la elaboración de las cuentas nacionales de un país. Involucra una serie de actividades tales como alojamiento, servicios de alimentación y bebidas, transporte, agencias de viaje, actividades recreativas y de esparcimiento, entre otras, por lo que su medición está determinada por la demanda, calculándose sus efectos en el consumo de los visitantes $u$ oferta de bienes y servicios para satisfacer esta demanda.

En el 2013 viajaron en el mundo 1087 millones de personas, que contribuyeron con el $9 \%$ del PIB mundial, el $6 \%$ de las exportaciones totales y dieron empleo a una de cada 11 personas, tanto en las economías avanzadas como en las emergentes (1). El principal país receptor de viajeros en el mundo fue Francia, que al año 2012 recibió 83 millones de personas, seguido de Estados Unidos con 66 millones. El tercer lugar lo ocupó China con 57,7 millones, superando a España que recibió 57,5 millones. En América Latina, México recibió el mayor número de turistas con 23,4 millones; seguido por Brasil con 5,7 millones; Argentina con 5,6 millones; República Dominicana con 4,6

millones; Puerto Rico, con 3,0 millones; Chile con 3,5 millones; Cuba y Perú con 2,8 millones; Colombia con 2,1 millones $y$ Uruguay con 2,7 millones.

Independientemente del crecimiento mundial turístico, lo importante es que el impacto de crecimiento en nuestro país y en la región Junín está en avanzada. El Perú, el 2013, recibió del exterior 3,1 millones de turistas, lo que representaría

1 Licenciada en Administración, magíster en Gestión Empresarial, especialista en Turismo Rural por la Universidad Nacional de Buenos Aires. 
apenas el 0,3\% del total mundial; sin embargo, el número de turistas internos al 2012 fue de 36 millones con un incremento del 18,2\% respecto al año anterior (2). Por otro lado, el año 2011, el Producto Bruto Interno Turístico peruano ascendió a $\mathrm{S} /$. 11 mil 688 millones, representando el 3,7 $\%$ del PBI total, de acuerdo a la Cuenta Satélite de Turismo (3). Asimismo, el turista extranjero efectúa un gasto promedio de S/. 3 230,00 durante su viaje al Perú, con una permanencia media de 12,6 noches, mientras que el turista interno gasta un promedio de S/. 318 y permanece 5,6 noches. Adicionalmente, el número de excursionistas fue de 57 millones en el año 2007, con un gasto promedio de S/. 58, principalmente en consumo de alimentos y bebidas $(39,6 \%)$, transporte $(15,6 \%)$ y compra de bienes $(41,6 \%)(4)$.

En cuanto a Junín, al año 2012, arribaron 956 mil turistas, en su mayoría nacionales $(99,4 \%)$, mostrando un crecimiento en promedio del orden de $9 \%$ en el periodo 2003-2011, figura $N^{\circ} 1$, que de mantenerse, significaría que al 2015 el número de arribos esté entre 1,25 millones y 1,3 millones. Comparativamente, al 2012, Lima recibió 16,8 millones de turistas nacionales y 1454110 de extranjeros que ingresaron por el Aeropuerto Internacional
Jorge Chávez; Cusco 800 mil turistas nacionales y 1,2 millones de extranjeros; Arequipa 1,4 millones de turistas nacionales y 298 mil extranjeros; Ica 893 mil turistas nacionales y 243 mil extranjeros (2). Por el total de arribos, Junín ocupa el octavo lugar a nivel nacional.

Junín tiene como capital a la "Ciudad Incontrastable" de Huancayo, y a una hora de distancia, por una carretera asfaltada, se encuentra la ciudad de Jauja, "primera capital del Perú" y donde está ubicado el principal aeropuerto Francisco Carlé. Huancayo está a $300 \mathrm{~km}$ de Lima, principal emisor de turismo en el Perú, pero la ruta por la Carretera Central se hace en aproximadamente 7 horas. Buenas vías de comunicación serían las limitantes principales para la llegada de visitantes con motivos de viaje que la región Junín está en condiciones de proporcionar, al poseer variados climas y espectaculares paisajes que se combinan en la sierra $y$ montaña de su territorio, como el lago Chinchaycocha en Junín y laguna de Paca, laguna de Ñahuinpuquio, nevados como el Huaytapallana, manifestaciones culturales como el convento franciscano de Santa Rosa de Ocopa, el Centro Piscícola El Ingenio y el Centro Arqueológico de Siquilla Pucara o de Tunanmarca, de Arhuaturo, de Unish

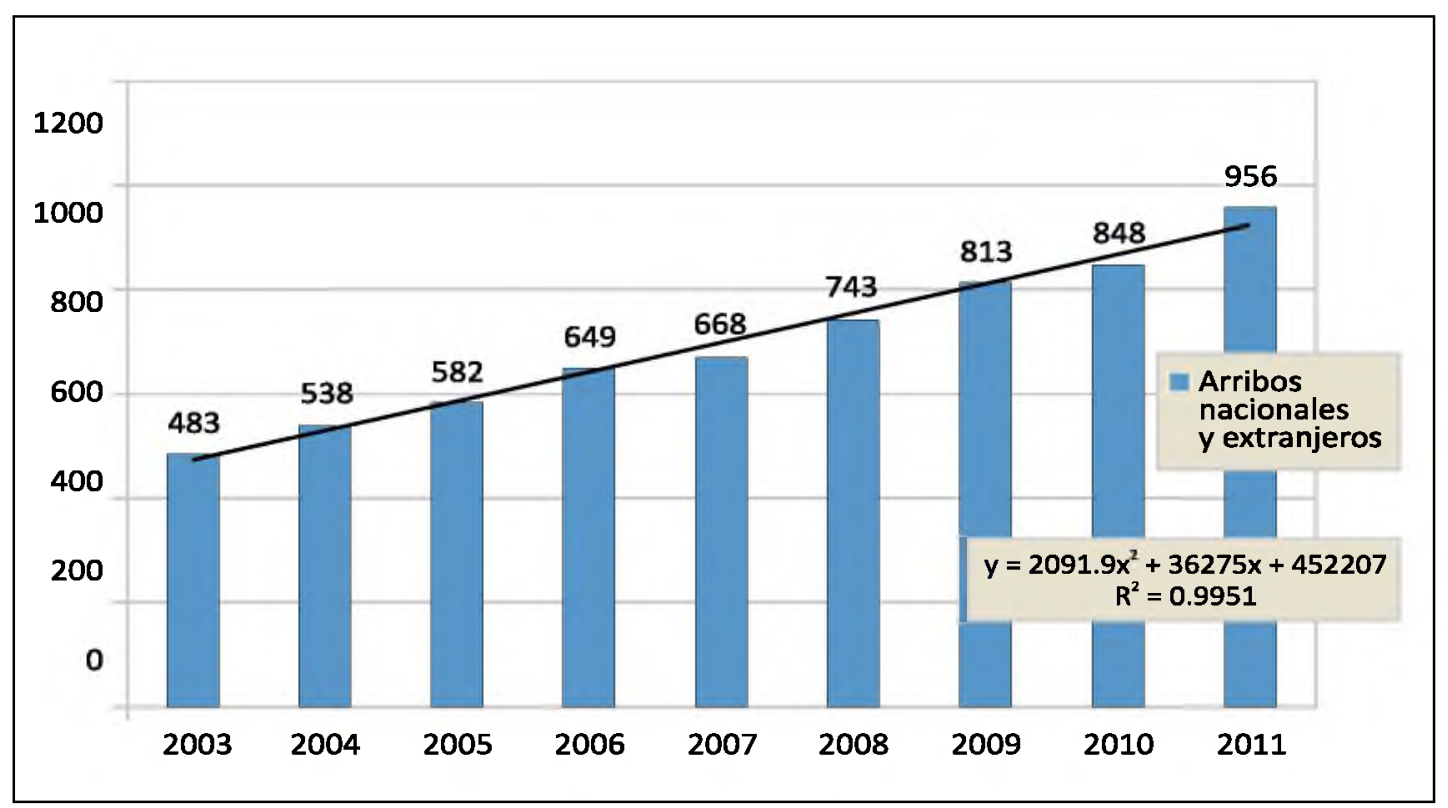

Figura $N^{\circ} 1$ : Arribos a Junín nacionales y extranjeros, 2003-2011 (miles).

Fuente: MINCETUR/SG/OGEE-OETA-Encuesta Mensual de Establecimientos de Hospedaje. 


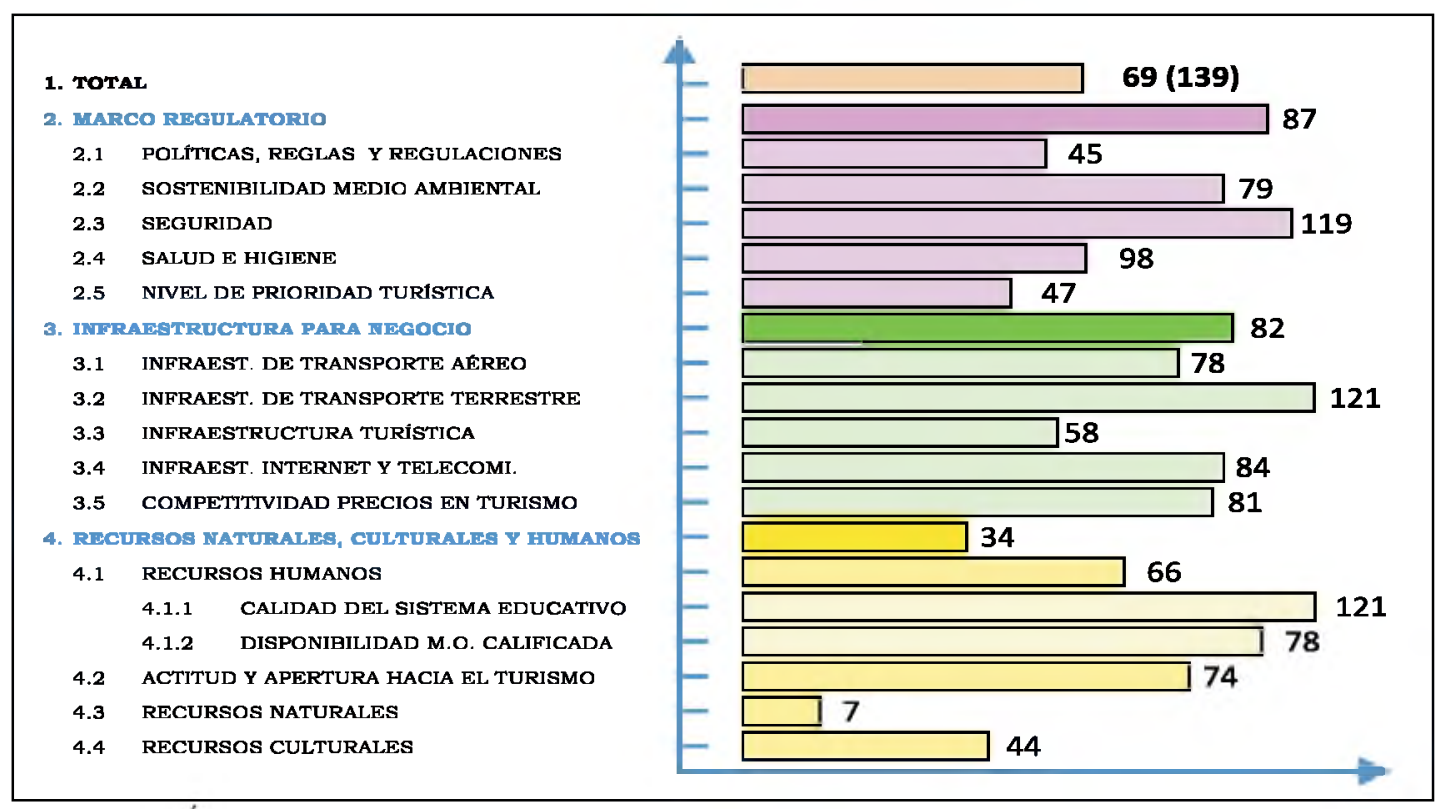

Figura $N^{\circ}$ 2: Índice de competitividad de viajes y turismo - Perú - 2012.

Fuente: The travel \& tourism competitiveness index 2011 , publicado por el Foro Económico Mundial.

Coto, de Corivinchos, etc.; pueblos como San Ramón, Chanchamayo, La Merced y Satipo (5), además de minas preincas, incas y republicanas capaces de convertirse en museos. Ante ello, el instrumento más importante es el Plan Estratégico de Turismo, que debe ser elaborado y aprobado como una señal de priorización de las perspectivas para el desarrollo turístico de la región.

La región Junín no registra un Plan Estratégico de Turismo aprobado, aunque existen propuestas trabajadas en los últimos años, como el Plan Estratégico de Desarrollo Turístico de Junín presentado por Cáritas Arquidiocesana de Huancayo, documento que recomienda 10 estrategias para el desarrollo del turismo, mereciendo destacarse "el fortalecimiento de las relaciones interinstitucionales Estado -Empresa-Universidad"; "formación y capacitación de recursos humanos"; "habilitación y adecuación de la infraestructura turística"; "desarrollo de productos turísticos estratégicos y de alta calidad" y "participación de poblaciones locales" (5), estrategias que deberán ser validadas por los consumidores, tour operadores, autoridades y poblaciones locales.

El Indice de Competitividad de Viajes y
Turismo que publica el Foro Económico Mundial, señala que el Perú, al año 2012, ocupa el séptimo lugar a nivel mundial en recursos naturales y el puesto 44 lugar en recursos culturales; sin embargo, el aprovechamiento de dichos recursos requiere de marcos regulatorios, infraestructura para el negocio y recursos humanos, donde el Perú muestra debilidades como se refleja en la figura $\mathrm{N}^{\circ}$ 2; entre las que destacan la necesidad de políticas públicas, reglas y regulaciones, sostenibilidad ambiental, seguridad, salud e higiene, infraestructura de transporte aéreo, infraestructura de transporte terrestre, infraestructura turística, infraestructura para internet y telecomunicaciones, precios y productos turísticos competitivos, recursos humanos calificados y buena actitud $y$ apertura hacia el turismo (6).

\section{CONCLUSIONES}

El Perú refleja poseer abundantes recursos naturales y culturales capaces de satisfacer los diversos gustos y preferencias de los visitantes. Resalta Junín como uno de los departamentos que atrae al $8 \%$ de los turistas internos, habiendo recibido 956 mil turistas en el año 2012, de los cuales un 99,4 
$\%$ eran nacionales, cuyo gasto promedio es de S/. 318,00 y permanencia de 5,6 noches. Sin embargo, para alcanzar el desarrollo del turismo, los recursos naturales $y$ culturales deben convertirse en productos turísticos con precios y calidad competitivos, con adecuada infraestructura en transporte terrestre, aéreo, acuático, con accesibilidad a los recursos turísticos, sostenibilidad ambiental, seguridad y recursos humanos capacitados, principalmente.

\section{REFERENCIAS BIBLIOGRÁFICAS}

1. World Tourism Barometer [Internet]. Madrid: Organización Mundial del Turismo; [Citado el 14 de noviembre 2014]. Tendencias del Turismo y estrategias de Marketing OMT [1 pantalla]. Disponible en: http://mkt. unwto.org/es/barometer

2. Ministerio de Comercio Exteriory Turismo [Internet]. Lima: Oficina General de Estudios Económicos; [Citado el 14 de noviembre 2014]. Estadística Mensual de Establecimientos de Hospedaje [1 pantalla]. Disponible en: http://www. mincetur.gob.pe/turismo/estadistica/ clasificados/actividad.asp

3. Ministerio de Comercio Exterior y Turismo. Cuenta Satélite de Turismo, año de Evaluación 2007. Lima: Oficina General de Estudios Económicos/M3A Editores SAC; 2011.

4. Ministerio de Comercio Exterior y Turismo. Encuesta Nacional de Viajes y Residentes (ENVIR), abril 2007-marzo 2008. Lima: Viceministerio de Turismo; 2009. Primera Edición.

5. Jorge Chávez Salas. Plan Estratégico de Desarrollo Turístico de Junín. Huancayo: Gobierno Regional de Junín/Cáritas Arquidiocesana de Huancayo; 2004.

6. World Economic Forum [Internet]. Cologny: World Economic Forum; [Citado el 14 de noviembre de 2014]. Travel \& Tourism Competitiveness Report 2012 [1 pantalla]. Disponible en: http://www3.weforum.org/docs/ WEF_TravelTourismCompetitiveness Report_2012.pdf 